
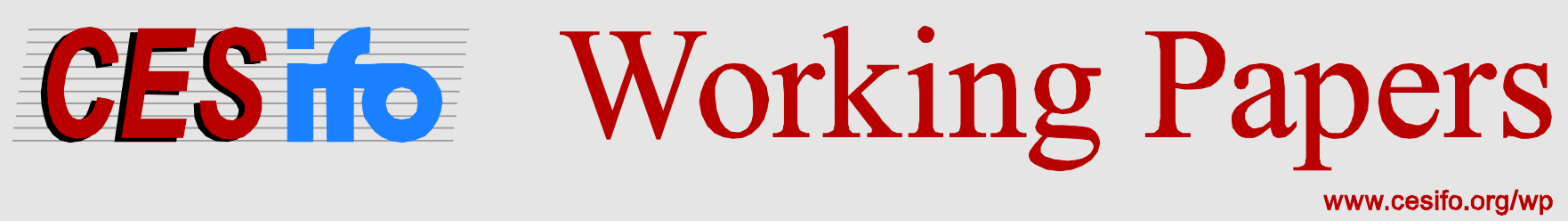

\title{
Compactness vs. Sprawl Revisited: Converging Views
}

\author{
Reid Ewing \\ Harry W. Richardson \\ Keith Bartholomew \\ Arthur C. Nelson \\ Chang-Hee Christine Bae
}

\author{
CESIFO WORKING PAPER NO. 4571 \\ CATEGORY 9: RESOURCE AND ENVIRONMENT ECONOMICS \\ JANUARY 2014 \\ An electronic version of the paper may be downloaded \\ - from the SSRN website: \\ - from the RePEc website: \\ - from the CESifo website: \\ www.SSRN.com \\ Www.RePEc.org \\ www.CESifo-group.org/wp
}




\title{
Compactness vs. Sprawl Revisited: Converging Views
}

\begin{abstract}
This paper examines the relative merits of compact cities or urban sprawl (suburban settlement patterns) as a spatial solution to environmental problems (such as climate control), automobile dependence, economic development, infrastructure costs and the quality of urban life.
\end{abstract}

JEL-Code: R140.

Keywords: compact cities, sprawl, vehicle miles traveled, carbon emissions, infrastructure costs, residential preferences, commuting times.

Harry W. Richardson

Doctor Honoris Causa of Autonomous University

of the State of Mexico

Palm Springs / California / USA

professorhwr@gmail.com

Reid Ewing

Arthur C. Nelson
Keith Bartholomew

Chang-Hee Christine Bae 


\section{Compactness vs. Sprawl Revisited; Converging Views}

Reid Ewing, Harry W. Richardson, Keith Bartholomew, Arthur C. Nelson and ChangHee Christine Bae

\section{Introduction}

In 1997, the Journal of the American Planning Association published a pair of pointcounterpoint articles now listed by the American Planning Association as "classics" in the urban planning literature (APA, 2006). In the first article, "Are Compact Cities Desirable?” Peter Gordon and Harry Richardson (GR) argued in favor of urban sprawl as a benign response to consumer preferences. In the counterpoint article, "Is Los Angeles-Style Sprawl Desirable?” Reid Ewing (E) argued for compact cities as an alternative to sprawl. GR and E disagreed at the time about almost everything: the characteristics, causes, and costs of sprawl, and the cures for any costs associated with sprawl.

In the intervening years, their views s have converged to some degree in response to empirical studies. The co-authors ${ }^{1}$ of this piece agree that sprawl and compact development represent two ends of a continuum of development types, characterized not only by density but by other variables. We agree that a given region's position along the continuum can be measured and related to public policy outcomes. We agree that market failures of one sort or another have contributed to sprawling development patterns. We agree that compact development may be undersupplied relative to current demand, and that this demand could increase because of demographic and lifestyle changes. We agree that sprawl and compact development have both costs and benefits, and that no development pattern is optimal in all respects. We agree that smart growth initiatives have had limited success to date, but that government might foster somewhat denser development patterns by raising the cost of auto use, relaxing local regulations on land use intensity and mix, and entering into partnerships with progressive developers.

It is time to reprise and recast the debate based on new research and writing on these and related topics. This article will summarize the literature since 1997 in several areas contested in the two original articles plus a few more rarely discussed, if at all, at that time (many of GR's arguments in 1997 have been elaborated in Gordon and Richardson [2007,2004, 2001a, 2001b, and 2000] in Richardson and Gordon [2009, 2000] and in Richardson and Bae [2005])..

\section{Operationalizing Sprawl}

Both GR and E used the term "compact" to describe one end of the development continuum, and "sprawl" to define the other end. Depending on the context, GR equated compact development to high density development, arguing that an urbanized area like Los Angeles is compact by virtue of its high average density. E defined

\footnotetext{
${ }^{1}$ For personal reasons Peter Gordon is not a co-author of this paper. However, he agrees with most of the views held under the acronym GR. Hence, the paper will continue to use it.
} 
sprawl in terms of four prototypes: (1) leapfrog or scattered development, (2) commercial strip development, (3) large expanses of low-density development, and (4) large expanses of single-use development (as in bedroom communities). Even this definition has its limitations, and was expanded to include any development pattern characterized by poor accessibility and lack of functional open space.

The first attempts to measure the extent of urban and suburban sprawl were crude. Several researchers created measures of sprawl that focused on density (Fulton et al. 2001; Malpezzi and Guo 2001; Nasser and Overberg 2001; Lopez and Hynes 2003; Burchfield et al. 2005). Density, as a measure of sprawl, has the big advantage of being easy to quantify with available data. The ease of measurement associated with the early sprawl indices, however, came with a lack of precision that led to wildly different sprawl ratings given to different metropolitan areas by different analysts. In one study, Portland was listed as the most compact region and Los Angeles was ranked among the most sprawling. In another, their rankings were more or less reversed (Glaeser et al. 2001; Nasser and Overberg 2001).

Most scholars now agree that sprawl is a multidimensional phenomenon (Galster et al, 2001; Malpezzi and Guo, 2001; Ewing et al, 2002; Cutsinger et al, 2005; Frenkel and Ashkenazi, 2008; Torrens, 2008; Jaeger et al., 2010; Mubareka et al., 2011).

However, this can lead to more questions than answers. What are the dimensions of sprawl? How are they best measured? Should these dimensions be combined into an overall sprawl index and, if so, how? Is sprawl in all dimensions necessary to call an urban area "sprawling"? Are tradeoffs allowed?

One of the early effort on measuring sprawl as a multidimensional construct was that of Ewing et al. (2002; 2003). They quantified sprawl in two steps: first, using principal component analysis, they developed indices for four components of urban form-development density, land use mix, activity centering, and street accessibility. They then combined the four factors into an overall compactness/sprawl index. The indices were constructed so that the more compact a metropolitan area was, the larger its index value. According to their indices for 2000, Portland, Oregon, metropolitan area had an index value of 126 and Los Angeles ended up near the middle of the pack, with an index of 102. Both the individual factors and overall index were validated against transportation outcome measures.

The original sprawl indices were made available to researchers who wished to explore the various costs and benefits of sprawl. Sprawl has been linked to physical inactivity, obesity, traffic fatalities, air quality, residential energy use, emergency response times, teenage driving, social capital, and private-vehicle commute distances and times (Ewing et al. 2003a; Ewing et al. 2003b; Ewing et al. 2003c; Kelly-Schwartz et al. 2004; Sturm and Cohen 2004; Cho et al. 2006; Doyle et al. 2006; Ewing et al. 2006; Kahn 2006; Kim et al.2006; Plantinga and Bernell 2007; Ewing and Rong 2008; Joshu et al. 2008; Stone 2008; Trowbridge and McDonald 2008; Fan and Song 2009; McDonald and Trowbridge 2009; Trowbridge 2009; Trowbridge et al. 2009; Lee et al. 2009; Nguyen 2010; Stone et al. 2010; Schweitzer and Zhou 2010; Kostova 2011; Zolnik 2011; Holcombe and Williams 2012; Griffin et al. 2013).

GR have no objection to these efforts to develop sprawl indices. However, they differ in their choice of variables, suggesting that the term lacks clear definition. Are the 
weights of the individual components of the sprawl index in Ewing et al. (2002) the same? Should metropolitan areas of different sizes be treated as comparable? For example, the spatial extent of Los Angeles (100+ miles from East to West and from North to South) has to result in a less dynamic downtown and larger city blocks in some but not all locations. While research on the multidimensional aspects of sprawl is interesting and may be useful, GR still believe that density remains the superior measure of sprawl.

\section{Causes of Sprawl}

Conceiving sprawl differently, there are different reasons for its proliferation. To GR, sprawl is a reflection of market forces. Considering the relatively the low cost of travel, residents and businesses prefer locations where land is inexpensive and congestion is moderate, which tend to be outlying. This leads to suburbanization patterns that are economically efficient. Technological innovations which allow interactions over great distances are another major trend.

EBN (Ewing, Bartholomew and Nelson) agree that cheap transportation and low cost land have led to suburbanization of jobs and housing, but do not equate suburbanization with sprawl. In their lexicon, sprawl patterns are dysfunctionally dispersed, whereas suburban development can be and often is relatively compact. All of the suburban downtowns (Dunham-Jones and Williamson 2009), nearly all of the new communities (Ewing, 1991; Ewing, 1996; Platt, 2011), most of the new urbanist developments (New Urban News 2003), and many of the transit-oriented developments (Cervero et al. 2004) and lifestyle centers (Robaton 2005) have sprouted in suburban locations. ${ }^{2}$ They do not meet the preceding definition of sprawl.

In contrast to GR, EBN view land markets as fraught with imperfections that induce sprawl. Perfectly functioning markets require many buyers and sellers, good information about prices and quality, homogeneous products in each market, no external costs or benefits, and so forth. The real estate market is imperfect in all of these respects. The rate of land appreciation is uncertain, resulting in land speculation and (where speculators guess wrong or land becomes legally encumbered) scattered development. Owner-occupied housing is subsidized through the tax code, a public policy that particularly benefits suburban residents who are primarily homeowners (there have been some Administration discussions about reducing mortgage subsidies and strengthening rent subsidies, but nothing has materialized so far). Outlying development may be subsidized through utility rate structures that are independent of distance from central facilities, although many utility facilities are decentralized and located near small towns and suburbs. The land market is rife with externalities, and government regulation may introduce additional market distortions by holding down densities and segregating land uses.

\footnotetext{
${ }^{2}$ Landscape Urbanism (Waldheim, 2006) is a new twist on New Urbanism, suggesting the natural environment and ecology are more important than the built environment. Although some of physical development could be quite compact it can never avoid the stigma of being a type of suburban (or exurban) sprawl.
} 
GR agree that there are no perfect markets but disagree on the extent of market failure and see it largely as a matter of externalities, which can and should be internalized (Gordon and Richardson,1993).

\section{Consumer Preferences}

The American Dream is often said to include a large lot home in the suburbs. A 1999 survey by the National Association of Homebuilders found that 83 percent of respondents preferred a detached single-family home "in an outlying suburban area" over a similarly priced urban townhouse accessible to public transit, work and amenities (NAHB, 1999). Similar preferences have been expressed in periodic surveys by Fannie Mae and in other studies (Lund, 2002; Morrow-Jones et al, 2004).

On the other hand, a recent survey by the National Association of Realtors (NAR 2011) offered respondents a choice between Community A and Community B. Community A was described as having only single-family houses on large lots, no sidewalks, shopping and other amenities at driving distances, ample parking at these places, and public transportation that is distant or unavailable. In contrast, Community B was described as having a mix of single-family detached houses, townhouses, apartments and condominiums on various sized lots, sidewalks on almost all streets, shopping and other amenities within a few blocks of home so you can walk or drive to them, limited parking at destinations, and public transportation is nearby. Faced with a choice, a majority (56 percent) of Americans surveyed chose Community B.

Bolstering these results, a national consumer survey by the global public relations company Porter Novelli found that 59 percent of U.S. adults now "support the development" of compact communities (defined in detail in the survey itself). Half would now be interested in living in a compact community (Handy et al. 2008). Levels of support were high among all groups except rural residents. More impressive than the absolute levels of support was the increase in support between survey years 2003 and 2005, a statistically significant 15 percent. The smart growth community was described identically and questions were phrased identically in the two survey years. The authors attribute the increase in media attention to sprawl and its costs.

These trends may accelerate. When it comes to housing demand, demographics are destiny, and some baby boomers prefer compact, walkable neighborhoods when they become empty nesters and retirees. By 2020, the number of individuals turning 65 years of age will skyrocket to more than 4 million per year. Households without children are another natural market for urban living. By 2025, only 28 percent of households will have children, while 34 percent will be one-person households (Nelson 2006). An alternative argument is that traditional families with children will continue to favor suburban life for much better public schools (saving the costs of expensive private schools), a more recreational environment in abundant outer space (both private and public).g Also, many DINKS still like a SFH with a substantial garden.. However, there could be 37 million more residential units on large lots than surveys indicate the market prefers. , One reason may be exclusionary local zoning practices (Pendall 1999).

There is some disagreement among the authors on the interpretation of these facts. The conclusion EBN draw is that while the vast majority of Americans want to live in 
single-family houses, they are willing to give up a large lot for urban amenities, and that this trend will accelerate. GR are skeptical. They accept that preferences can change, but they are hesitant to predict long-term outcomes, such as that by 2025 most housing demand will be for small lot urban living (Nelson, 2006). Their problem with the surveys on both sides is that they are based on contingent valuation, i.e,. answers to hypothetical questions. Their view is that analysis should be based on revealed preferences, i.e., real world housing choices. However, revealed preferences are based on past and present not future decisions, and it is speculative to use them as a predictor. In many cases, housing choices can be changed often without higher monetary costs. Changes in preferences are better analyzed by trend data year-byyear.

Theoretically, if the market favors compact development, demand should be reflected in the prices people are willing to pay it. Some studies (e.g. Bartholomew and Ewing, 2011; Duncan, 2011) suggest price premia for prices in compact neighborhoods, especially near rail transit stations, and in New Urbanist communities. Leinberger (2008) points out that in 2003 prices per ft.2 for condominiums/townhomes were higher than those for single family homes nationwide for the first time (possibly reflecting high-cost internal facilities,e.g. kitchens and bathrooms) . Because demand may be greater than the current supply, the price-per-square foot values of houses in mixed-use neighborhoods show price premia ranging from 40 to 100 percent, compared to houses in nearby single-use subdivisions. Given this market performance, it is no surprise that the Urban Land Institute's Emerging Trends in Real Estate (ULI and PricewaterhouseCoopers 2005, 2006, 2007) has for many years put downtown and in-town housing at the top of its list of hot real estate markets. On the other hand, in many metropolitan areas in the recovery from the recent severe housing recession condominium price increases have lagged behind those of SFHs.

\section{Subsidies and Public Goods}

Consumer preference and technological innovations help explain suburbanization and decentralization of activities within metropolitan areas. But they cannot explain the extent of dispersal, nor the absence of mixed land uses, nor the loss of valuable natural areas. We must look to market failures to explain these phenomena.

Sprawling developments basically cost more to build and service than the taxes or fees they generate. Some research indicates that the housing/infrastructure costs vs. distance (or density) function is U-shaped. When a new development is built outside of an existing community, roads, utilities, schools, and emergency facilities have to be built to service them. In most cases, the costs of this infrastructure is not fully covered by the developers or new residents, but instead are subsidized by the general taxpayer?

The biggest subsidies are for the highway system. If drivers had to cover the full social costs of automobile use-including vehicle emissions, free parking, uncompensated accident costs, and other external costs (Delucchi, 1998; Litman, 2009), they might opt for other development patterns to minimize auto dependence (Cortright, 2008). They might, but not necessarily; there is doubt whether drivers make that choice. Instead, planning decisions may enforce it.. 
Homebuyers purchase a whole bundle of attributes, some specific to the house itself and some to its environs. So-called residential and environmental amenities are part of the bundle. Most are public goods, in the sense that one resident's consumption does not affect another's and no resident can be denied access to these goods. Public goods tend to be undersupplied by the private market because of the "free rider" problem, that is, the inability to charge beneficiaries for the value they receive (or even to ascertain what it is worth to them). However, a significant proportion of the housing stock is in private (often gated) communities where many services are provided privately.

The best example is open space. Greenbelts and other open spaces, if designed for physical or visual access, can enhance property values of nearby developable lands (Bartholomew and Ewing 2011; other recent cites). Yet, as a public or quasi-public good, open space tends to be undersupplied because land owners cannot capture the value to those around them. This is particularly true of small development sites, where most of the value of any preserved open space accrues off-site.

For this reason, all types of open space are undersupplied or underpreserved, including farmland. "The benefits of looking at farmland are perceived by many people, but each one may understate his individual willingness to pay for such benefits. A collective arrangement may be required to overcome this free rider problem when beneficiaries are numerous" (Fischel 1985, 287). A question rarely discussed is: How important is farmland preservation given the long-term decline in the volume of cultivated land?

\section{Land Use Regulation}

Does government regulation of land introduce market distortions? The literature since 1997 seems to suggest so, but there are also caveats. Levine (2006) argued that extensive use of restrictive low-density zoning constrains the exercise of a free market in real estate and that denser urban development would result from a more open market. In other words, one of the causes of sprawl is our current system of locally controlled zoning regulations that mandate the construction of sprawl. This is a contention loudly voiced by New Urbanist planners. One idea, but probably difficult in practice, is to get rid of R-1 zoning and similar restrictions.

Levine supports this contention in a number of ways, some more compelling than others. First, he cites studies showing that municipal zoning lowers densities and creates more exclusivity in suburban communities (2006, p. 52). Much of this evidence, however, is already out-of-date. Hundreds of jurisdictions have recently amended zoning ordinances to allow dense, mixed-use, transit-oriented development at least in certain districts.

Land developers perceive land use regulation as the principal barrier to "alternative development" forms, particularly dense development. Almost half of the developers proposing such alternatives point out that they have been turned down by planning authorities. Of course, land developers may have biased views when it comes to dealings with local government. High-density development can be more profitable because of much lower land costs. 
Additional evidence comes from household preference surveys in Atlanta and Boston (pp. 149-162). Levine finds that a significant number of households in Atlanta live in neighborhoods that are less walkable than they would ideally choose. ${ }^{3}$ Of course, there could be other explanations for this (e.g., inertia of the development community), irrespective of land-use regulation.

Generally, both sets of authors agree that land use regulation has contributed to sprawl, but GR view it as more important than do EBN in light of zoning reform initiatives in hundreds of jurisdictions.

\section{Costs and Benefits of Sprawl}

Urban planners are ultimately less interested in development patterns, per se, than in the costs and benefits of one pattern versus another. That is to say, there are no inherently good or bad patterns, only good or bad outcomes. The loaded term "sprawl" has come to be applied to certain development patterns because of their documented negative outcomes. The following review focuses on costs of sprawl that have been extensively researched since the 1997 point-counterpoint articles. It also touches on some of the apparent benefits.

\section{Car Dependency}

In 1997, GR argued that "... the link between high-density development and reduced VMT (vehicle miles of travel), and hence reduced energy consumption, is by no means clear." This statement, which was questionable in 1997, is even more dubious today. However, it is true that among built environment factors, density may not be the most important influence on VMT, travel choices, and vehicle ownership. Stop-go traffic in high-density areas increases both fuel consumption and air pollution.

The effects of the built environment on transportation and travel behavior is confirmed by more than 200 empirical studies. This literature is summarized in recent reviews by Cao et al. (2009), Heath et al. (2006), Pont et al. (2009), Graham-Rowe et al. (2011), and Litman and Steele (2011), and Salon et al. (2012), and in metaanalyses by Leck (2006) and Ewing and Cervero (2010).

In these studies the built environment has been characterized mainly in broad terms referred to as the ' $D$ ' variables (see reviews by Ewing and Cervero 2001; Handy 2005; Ewing et al. 2005). The original three Ds, coined by Cervero and Kockelman (1997), are density, diversity, and design. The Ds were later expanded to include destination accessibility and distance to transit (Ewing and Cervero 2001).

Ewing and Cervero (2010) in a meta-analysis measured the effect sizes in terms of weighted average elasticities ${ }^{1}$ for all five of the $\mathrm{D}$ variables using more than 60 studies. The results, which are shown in Table 3, indicate that density, the $\mathrm{D}$ variable

\footnotetext{
${ }^{3}$ On a related point, Bertaud and Richardson (2004) estimated what it would take to increase transit supply by rail dramatically throughout Atlanta's metropolitan areas. The financial cost would have been enormous because it would require meeting a reasonable standard of walkable distances to transit stations. The estimate had to be based on 138 transit stations and about 2,000 miles of track.
} 
that generates the most controversy, has the smallest impact on VMT. Destination accessibility has the largest. Measures of diversity, design, and distance to transit are intermediate.

Table 1. Weighted average elasticities of VMT with respect to built-environment variables.

\begin{tabular}{|c|c|c|c|c|}
\hline & & $\begin{array}{l}\text { Total number } \\
\text { of studies }\end{array}$ & $\begin{array}{l}\text { Number of } \\
\text { studies with } \\
\text { controls for self- } \\
\text { selection }\end{array}$ & \begin{tabular}{|l} 
Weighted \\
average \\
elasticity \\
of VMT \\
(e) \\
\end{tabular} \\
\hline \multirow{2}{*}{ Density } & Household/population density & 9 & 1 & -0.04 \\
\hline & Job density & 5 & 1 & 0.00 \\
\hline \multirow[t]{2}{*}{ Diversity } & Land use mix (entropy index) & 10 & 0 & -0.09 \\
\hline & \begin{tabular}{|l} 
Jobs-housing balance \\
\end{tabular} & 4 & 0 & -0.02 \\
\hline \multirow[t]{2}{*}{ Design } & Intersection/street density & 6 & 0 & -0.12 \\
\hline & \% 4-way intersections & 3 & 1 & -0.12 \\
\hline \multirow{3}{*}{$\begin{array}{l}\text { Destination } \\
\text { accessibility }\end{array}$} & Job accessibility by auto & 5 & 0 & -0.20 \\
\hline & Job accessibility by transit & 3 & 0 & -0.05 \\
\hline & Distance to downtown & 3 & 1 & -0.22 \\
\hline $\begin{array}{l}\text { Distance to } \\
\text { transit }\end{array}$ & $\begin{array}{l}\text { Distance to nearest transit } \\
\text { stop }\end{array}$ & 6 & 1 & -0.05 \\
\hline
\end{tabular}

From GR's perspective the problems are the overall low elasticities that indicate that even compactness has little impact on VMT and the evidence that VMT growth rates (especially per capita) are slowing down and perhaps flattening out. For more views about transportation and urban compactness see Richardson and Bae (2007).

\section{Traffic Congestion}

GR asserted that sprawl, which they equated to suburbanization, has benign effects on traffic congestion. "Suburbanization has been the dominant and successful mechanism for reducing congestion. It has shifted road and highway demand to less congested routes and away from core areas. All of the available recent data from national surveys on self-reported trip lengths and/or durations corroborate this view" (Gordon and Richardson, 1997, p. xxx). E challenged this view by citing increases in average commute times from Census to Census. Neither article looked directly at congestion levels.

At the time these assertions and counter-assertions were written, sprawl measures had not yet been developed. Now that they have been, we have more direct evidence on the relationship between sprawl and congestion. Ewing, Pendall, and Chen (2002) found no association between their overall metropolitan sprawl index and either mean journey-to-work time in minutes or annual traffic delays per capita. The individual dimensions of sprawl seem to neutralize each other. While VMT is higher in sprawling areas, so apparently are average travel speeds. Using the same sprawl index as Ewing, Pendall, and Chen and a different source of commuting data, Kahn (2007) concluded that sprawling areas have an edge with respect to both travel speeds and overall commuting times. "Relative to workers in compact cities, workers in sprawled cities commute an extra 1.8 miles further each way but their commute is 4.3 
minutes shorter. Over the course of a year (400 trips), they save 29 hours. While the workers living in sprawled cities have a longer commute measured in miles, they are commuting at higher speeds...workers in sprawled cities commute at a speed 9.5 miles per hour faster than workers in compact cities” (Kahn 2007, p. 6).

\section{Air Quality and Climate Change}

In 1997, GR argued that advances in vehicle emission control technology would solve our air quality problems. They were at least partially right. Cleaner cars have contributed to dramatic improvements in urban air quality, even as VMT has grown three times faster than population. Still, metropolitan areas containing more than 40 percent of the U.S. population fail to meet national ambient air quality standards for one or more regulated pollutants, and transportation sources are one of the main contributors to the problem (US EPA 2010; Marshall et al. 2005; Dannenberg et al. 2003). The transportation sector alone accounts for 55 percent of nitrogen oxide (NOx) emissions and 31 percent of volatile organic compound emissions, precursors of ozone (US EPA 2001; Frank et al. 2000). However, technology is making a big difference in reducing vehicle-related air pollution. The biggest change is the stop-go system that automatically turns off the engine at stop lights, etc. The estimate of pollution reduction varies, but may be as high as 15 percent. It is widespread in newer cars in Europe but as yet is only in few cars in the US (mainly European cars, e,g, Volvo); it can spread quickly here, however. "Cold starts," a phenomenon associated with more and shorter trips, is also remediable technologically, despite negligible implementation hitherto.

Can compact development reduce air pollution and greenhouse gas emissions? The answer is complicated. Using the sprawl measures described above, Ewing, Pendall, and Chen (2002) found that maximum 8-hour average ozone levels were higher in sprawling than in compact areas. This result was confirmed by Stone (2008), who found that large metropolitan regions ranking high on sprawl experience a greater number of higher ozone levelss than more spatially compact metropolitan regions. Importantly, this relationship was found to hold after controlling for population size, average ozone season temperatures, and regional emissions of nitrogen oxides and volatile organic compounds, suggesting that urban spatial structure may have effects on ozone formation that are independent of its effects on precursor emissions from transportation, industry, and power generation facilities. Yet, ozone levels (because of diffusion) are more dependent on location, topography and climate than on urban spatial structure. Also,, a more recent study by Schweitzer and Zhou (2010), while confirming that ozone concentrations are significantly lower in compact regions, also found that human exposure to ozone was higher in these regions because more people live in areas where emissions are concentrated.

Regarding the greenhouse gas emissions, Ewing et al. (2008) estimated that, considering market penetration and base levels of sprawl, compact development could reduce aggregate metropolitan VMT, and as a result greenhouse gas emissions, by 12 to $18 \%$ in 2050 , as compared to a future of sprawl. Once again, however, technology is more important than VMT reduction. 
For a different view, the National Academy of Sciences (NAS, 2007) projected reductions in VMT and associated $\mathrm{CO} 2$ emissions of about 1 percent below trend by 2030, growing to between 1.3 and 1.7 percent below trend by 2050. In their "upperbound" scenario, the NAS committee projects reductions in VMT and associated energy use and CO2 emissions of 7 to 8 percent below the base case by 2030, growing to between 8 and 11 percent below the base case by 2050 .

The potential of technology to counter VMT trends is limited; this point was challenged by GR above. The Center for Clean Air Policy projects that the benefits of improved fuel economy standards and less carbon intensive vehicle energy sources would be largely negated by the growth of VMT at the rate seen before the recession. To be on a climate stabilizing path toward 80 percent reduction in $\mathrm{CO} 2$ emissions by 2050, overall VMT could only increase by 5 percent between 2005 and 2030, and VMT per capita would have to decline by 12 percent to meet the CCAP target. However, there are so many behavioral factors influencing VMT change, e.g. the aging of the population. Even with a 60 mpg Corporate Average Fuel Economy (CAFÉ) standard by 2035 and a 15 percent decrease in the carbon intensity of vehicle fuels, the growth of VMT would prevent the target from being reached. The auto manufacturers' agreement to aim for a 53.5 mpg CAFE standard by 2025 certainly create the possibility that fuel economy and carbon intensity may reach or exceed these assumptions by 2035 .

\section{Energy Security}

The literature on the association between energy consumption and urban form is well-established (Alberti, 1999; Andrews, 2008; Bento et al. 2003; Burchell et al. 1998; Cooper, Ryley \& Smyth, 2000; Ewing and Rong, 2008; Kahn, 2007; Saunders, et al., 2008; U.S. Environmental Protection Agency 2003). In 1997, GR argued that a "global energy glut," weakness of the OPEC cartel, and low real price of gasoline made energy impacts of sprawl not worth worrying about. E (1997, p. 114) countered with the following: "While the best case envisioned by $\mathrm{G} \& \mathrm{R}$ has the real price of gasoline holding steady, it is the worst case that worries others... 'The fact that the most recent large-scale war fought was in the Persion Gulf is itself testimony to the risk of relying on the political stability of this region for a commodity so essential to economic activity..."”

The reference projection from the Energy Information Agency (EIA) estimates that U.S. petroleum use will increase by $6.25 \%$ between 2005 and 2035 and China's will increase by a staggering $152 \%$, bringing it to within $76 \%$ of the U.S. consumption level (EIA 2010). While neither set of authors expect "peak oil”" to be reached anytime soon, we agree that it must be reached as some point, and oil prices will continue to increase slowly before then, and rapidly afterwards. EIA's Annual Energy Outlook 2013 projects that in the reference case (most likely), the real price of oil will increase from about \$100 per barrel today to over \$160 per barrel in 2040 . 
Crude Oil Spot Prices for Three Scenarios, 1990-2040 (2011 dollars per barrel)

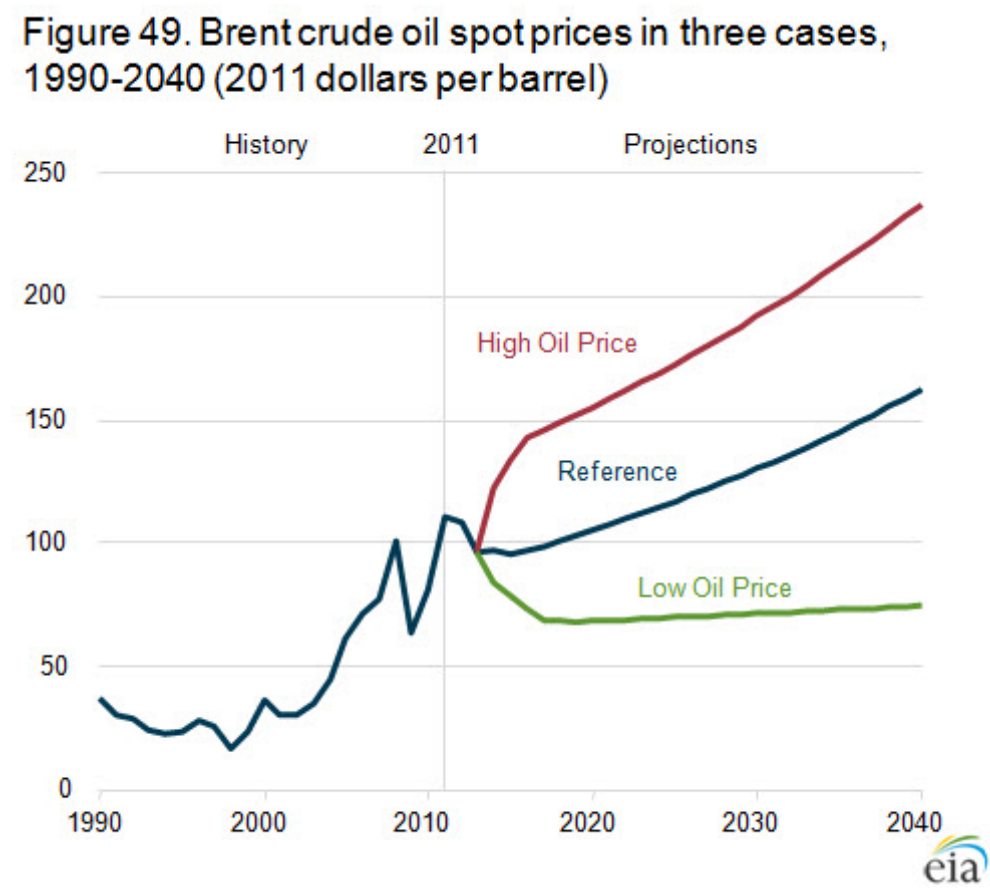

Source: Energy Information Administration, Annual Energy Outlook, 2013. Another point, focusing on buildings, is that high-rise development (especially in the non-residential sectors) is energy-intensive.

\section{Physical Activity, Obesity, and Public Health}

There has been increasing attention given to non-motorized transportation modes (walking and cycling) since 1997. This has been motivated by public concern over physical inactivity, rising obesity, and the chronic health problems that accompany them. These trends have occurred at the same time that sprawl has increased, causing some to draw causal inferences. The Centers for Disease Control and Prevention, and subsequently the Robert Wood Johnson Foundation, have allocated very substantial resources to testing these inferences. But as every researcher knows, correlation does not imply causation, and the jury is still out on whether sprawl is contributing to the obesity epidemic.

The literature on the built environment and physical activity has expanded exponentially as funding has become available for active living research. The literature is now so vast there are reviews of the many reviews (Bauman and Bull, 2007; Gebel, Bauman, and Petticrew, 2007; Ding and Gebel, 2012). The first study on association between sprawl and obesity was conducted by $\mathrm{E}$ and colleagues (Ewing et al. 2003). They found that after controlling for sociodemographic and behavioral covariates, adults living in sprawling counties walked less, weighed more, and were more likely to be obese and to suffer from high blood pressure than those 
living in compact counties. Seventeen of the 20 studies published since that study have established statistically significant links between some aspect of the built environment and obesity (Papas et al. 2007). But the causal pathway is still far from clear, because physical activity does not vary enough from place to place to account for variations in obesity.

While no one can deny that a combination of diet and exercise is very healthy, GR believe that exercise is not the solution to obesity, and that the built environment plays a limited role in the obesity epidemic. Nutritionists have come around to the view that eating less is a much more efficient approach because burning enough calories through exercise is rarely sufficient and is often followed by eating more calories. Promoting modifications in physical planning to deal with obesity is a form of social engineering while encouraging better eating shifts attention to personal responsibility and accountability.

There is much more on this issue according to GR:

i. The modal shares of bicycling and walking have changed very little.

ii. Walking and bicycling are healthier in suburban environments because of less air pollution (especially PM) and noise than in compact locations.

iii. The growth in telecommuting (not particularly healthy) is outweighing the influence of transit, walking and bicycling, modal share aspects of compact spatial structure (Zhu, 2013; 2012).

iv. Because it usually burns more calories home and/or gym exercise has better health effects than walking outside.

\section{Infrastructure and Public Service Costs}

Many studies report savings on infrastructure costs as densities rise. This makes sense. Infrastructure costs, some of which are fixed, are amortized over more units at higher densities. Economies of scale kick in. However, in 1997, GR viewed such studies, even the most carefully crafted, as badly flawed, and cited one study showing that public service costs are highest at very high densities. In response, E made the distinction between infrastructure costs, which he argued are lower at high densities, and public service costs, which initially rise, then fall, and then rise again as densities increase (the U-shaped function was identified two decades ago; Ladd, 1992). E also argued that as with travel, density is not as important as other D variables in determining infrastructure and public service costs.

Subsequent to GR and E's debate, Bob Burchell and colleagues at Rutgers University conducted a comprehensive literature review and an alternative growth scenario analysis to answer the cost question once and for all. In the literature review, Burchell et al. (1998) concluded that there is "general agreement" in the technical literature that infrastructure costs are higher with sprawl, and "some agreement" that public service costs are higher. In the alternative growth scenario analysis, Burchell et al. (2002) concluded that national savings with "controlled growth" as compared to "uncontrolled growth or sprawl" would be positive but relatively modest. For water and sewer infrastructure, savings would be just under 7 percent. For road infrastructure, savings would be just under 12 percent. For local public service costs, savings would be just under 3 percent. 
Burchell's analysis was based on hypotheticals, what GR had previously dismissed as a "prospective view of the comparative costs of alternative types of development under sets of very precise assumptions." In another study based on real public outlay data Carruthers and Ulfarsson (2003) examined how the character of urban development affected per capita public expenditures in a cross section of 283 metropolitan counties during the 1982 - 1992 time period. A separate equation was estimated for each measure of expenditure, providing substantive evidence on how density, the spatial extent of urbanized land area, property value, and political fragmentation affect the cost of services. The parameter estimates for density were negative and significant for capital facilities, roadways, police protection, and education. ${ }^{4}$ Again, however, density is only one dimension of sprawl, and the others may be more significant.

\section{Housing Affordability and Racial Desegregation}

The evidence regarding sprawl's impact on housing affordability and racial desegregation is mixed. Kahn (2001) has shown that, controlling for household income and metropolitan patterns of racial segregation, sprawl was significantly and positively related to closing the gap between black and white rates of suburban homeownership between 1980 and 1990. In other words, sprawling metropolitan areas provide greater opportunities for suburban homeownership for black households. The study also found that blacks are more likely to own larger homes in sprawling regions. This is said to be a direct result of more affordable housing in sprawling metropolitan areas. However, Kahn's methodology in measuring a region's level of sprawl, which considered only the proportion of jobs located within a 10 mile radius of a city center, has come under some criticism. Under Kahn's criteria, for example, the expansive Phoenix, Ariz. area qualified as one's of the nation's least sprawling cities, while Washington, D.C. and Chicago, Ill. were designated as among the nation's most sprawling metropolitan areas.

Kahn (2007) subsequently used the broader sprawl index of Ewing, Pendall, and Chen (2002) to test for housing effects. Home ownership rates are 8.5 percentage points higher in the most sprawled cities relative to the most compact cities. The median household in a compact city lives in a unit with 158 fewer square feet than the median household in a sprawl city. Minorities also appear to benefit from sprawl in terms of the number of rooms in the housing unit. Surprisingly, while Kahn (2007) had the data to do so, he did not conduct a multivariate analysis of general housing consumption vs. sprawl, controlling for such important demographic features as household income, household size, and the presence of children.

A 2007 study (Galster and Cutsinger, 2007) analyzing the relationship between land use patterns and levels of black and white segregation in 50 U.S. metropolitan areas found a direct correlation between sprawl and desegregation. They surmised that "the dominant relationship observed is that, on several measures, more sprawl-like land use patterns are associated with less segregation” (Galster and Cutsinger, 2007,

\footnotetext{
${ }^{4}$ Some international studies, such as one on Spain by Hortas-Rico and Sole-Oile (2010), have a close association between low-density municipalities and higher local public service costs. Although this paper primarily focuses on the United States, Richardson and Bae (2004) examine comparisons and contrasts between the United States and Western Europe (especially France and the United Kingdom) on many sprawl issues.
} 
p. 540) They identified the land/housing price effect as the dominant mechanism through which land use patterns influence black and white segregation measures .

On the other hand, Nelson, Sanchez, and Dawkins (2004) found that urban containment measures were effective at reducing black and white segregation levels in designated metropolitan areas between 1990 and 2000. Likewise, Wassmer and Baaas (2006), using a more extensive analysis of sprawl factors, found that more centralized metropolitan areas have lower median home values than sprawling regions (this contrasts with the compact city house price premium argument).

Another dimension of the links between housing affordability, racial segregation and infrastructure and services is the debate about the value of common interest developments (CIDs), ranging from gated communities (Blakeley and Snyder, 1997) to planned developments and even some condominiums (T.M. Gordon, 2004). CIDs are widely believed to high-income and largely segregated. Blakeley and Snyder takes this view, while Tracy Gordon qualifies it to some degree. On the other hand, because both infrastructure and services are privately supplied in many CIDs (and in California at least this type of CID accounts for quite a large and increasing share of the new housing stock) this alleviates the burden of public sector provision.

\section{Central City and Downtown Decline}

GR and E did not debate the effect of sprawl on central cities and downtowns, because of the lack of empirical evidence. Instead, they debated whether central cities and downtowns were in decline. GR dismissed central cities as economic losers in the competition for jobs. They criticized downtown renewal programs as an inefficient use of public money. E took the opposite position.

A key 1999 analysis of 162 U.S. urbanized areas (Downs, 1999) used nine different variables, especially the geographic size of the urbanized area, gross population density in the urbanized fringe, and the ratio of central city density to outlying fringe density. Central city decline was measured in terms of central city population changes, poverty rates, crime rates, income per capita, and the percentage of older housing. Hundreds of regressions led to the conclusion of "no meaningful and significant statistical relationship” between a city's level of sprawl and its extent of urban decline.

Using other variables Nelson et al. (2006) found that cities with urban containment measures were more effective in channeling development into downtown areas. The success of central cities in attracting real estate development was measured in terms of the number of residential units constructed and the total value of nonresidential construction. Urban containment was measured by formally adopted growth boundaries, service extension limits, greenbelts and other policy mechanisms.

\section{Other Impacts}

Some other research conducted (much of it by EBN) since the 1997 debate suggests the association between sprawl and income growth (Nelson \& Foster 1999; Nelson 
\& Peterman 2000); consumption of farmland (Nelson 1992; Nelson \& Sanchez 2005); residential neighborhood quality (Nelson, Dawkins \& Sanchez 2007) and traffic safety (Ewing, Pendall, and Chen 2002; Ewing, Schieber, and Zegeer, 2003; Trowbridge, Gurka, and O’Connor 2009).

GR challenges these findings with the exception of farmland protection. Many of the results gleaned from the many research studies cited by EBN, illustrating correlations and relationships between built environment, socioeconomics, and outcome variables, rely heavily on how the sprawl indices are constructed. All of them are highly subjective and depend upon very specific and not necessarily generally accepted definitions of sprawl.

\section{Sprawl Remedies}

GR suggest the imposition of congestion charges and emission fees as shadow prices for external costs of automobile use, specifically for traffic delays and air pollution imposed on others. E, however, believes in proactive planning as the solution to sprawl. The common practice of local governments in the U.S., to wait for property owners to come forward with rezoning requests, is not planning but reacting.

In truth, however, neither GR nor E paid enough attention to issues of implementation and program effectiveness. Growth management and smart growth initiatives have had, at best, mixed results. Policy implementation is harder than policy formulation (Ewing 2006).

Sartori, Moore, and Knaap (2011) recently concluded that Maryland, the nation's presumed leader in smart growth, is making only slow and barely discernible progress towards smarter growth. Their study, the most comprehensive assessment of Maryland's smart growth program to date, found that in several smart growth performance measures such as multifamily housing construction, per capita vehicle miles traveled, housing affordability, and compact development, Maryland has largely tracked national trends, and has not measurably gained ground over the last decade.

Portland, Oregon (the Mecca for planners) has received the most attention. Hoever, even there the evidence is not clear-cut. GR did a comparison of Portland and Los Angeles and found that apart from size, density and racial mix there are more similarities than differences (Richardson and Gordon, 2004). Jun's analysis showed that the effects of the Urban Growth Boundary had little impact on suburbanization and that leapfrog development increased commuting lengths in some areas (Jun, 2004). He also demonstrated the transit-oriented development (TOD) had no clear effects in reducing automobile use. Orenco Station is regarded that as one of the nation's most successful TOD communities, yet about three-quarters of its commuters travel to work by car rather than by MAX, the light rail system (Bae, 2002; it has not changed much in the last decade). However, many non-work trips (more than fourfifths of total trips) are by walking, bicycling and transit. Also, although not very large (about 11 percent) there are commutes by bicycle and even by foot to the nearby Intel establishments. Another limitation of the effectiveness of the Urban Growth Boundary is that, especially in the 1990s at a time when Washington State's Growth Management Act had barely got under way, many households relocated across the 
river to nearby Clark County, Washington, which provided a key safety valve minimizing the effects of growth management restrictions (Bae, 2004b).

Landis (2006) evaluated a host of growth management and control programs in place in California. With respect to controlling growth, some types of programs, principally residential caps, annexation controls, and voter-enacted super-majority approval requirements, do appear to significantly limit population growth in the cities that adopt them. They cannot be said to discourage sprawl, only to shift growth elsewhere. Again, that is not good news for growth management advocates. With respect to relocating growth, depending on the particular programs and circumstances, growth management programs were associated with an increased likelihood of infill development in the cities that adopted them, and with growth displacement to nearby communities. The former presumably discourages sprawl, but the latter may have the opposite effect.

Rodriguez, Targa, and Aytur (2006) studied the impact of containment policies on population density and vehicle miles traveled per capita. Their empirical analysis relied on panel data for the largest 25 metropolitan areas in the U.S. Findings suggested that local containment policies and state-level involvement in enabling or mandating growth management are associated with higher population density but also more vehicle miles traveled. This unanticipated relationship to miles traveled underscored the importance of a coordinated strategy to mitigate some of the potential travel consequences of containment policies.

One argument that was highlighted more than a decade ago was that population growth was a source of sprawl, and because international immigration accounted for a large share of population growth then it contributes to sprawl. This appears to have faded more recently because it has not been revived among those who would like tighter rather than laxer immigration controls. In fact, hitherto immigration results in higher densities and more compactness (Bae, 2004a) and immigrants account for only a tiny proportion of the new housing stock more of which is built in sprawling communities.

Pendall (2000) tested the cumulative influence of locally adopted (municipal) land-use controls on sprawl. Land-use control variables, relating to zoning, urban growth boundaries, permit moratoria, building-permit caps, and adequate public facilities ordinances, were collected in a survey of 1,510 jurisdictions in the 25 largest metropolitan areas of the U.S. Sprawl was measured in terms of changes in county net densities. Impact fees and other charges that shift the cost of development onto builders and away from the general public were found to reduce sprawl; those that mandate low densities were found cumulatively to increase sprawl, while urban containment mechanisms such as urban growth boundaries had limited cumulative effects.

Aytur et al. (2008) examined relationships among urban containment policies, state adoption of growth management legislation, and population levels of leisure and transportation-related physical activity in 63 large metropolitan statistical areas. Strong urban containment policies were associated with higher population levels of leisure-time physical activity and walking/bicycling to work during the study period. Additionally, residents of states with legislation mandating urban growth boundaries reported significantly more minutes of LTPA/week compared to residents of states 
without such policies. However, weak urban containment policies showed inconsistent relationships with physical activity.

Filion (2006) found that despite aggressive efforts in Metropolitan Toronto to promote the development of nodes as an alternative to sprawl, the success of these efforts have been mixed. While three planned suburban nodes enjoyed intense development over the 1980s, development at smaller centers was largely stagnant. Moreover, Filion found that nodal public transit ridership and pedestrian activity "remains well short of planning objectives" (Filion 2006).

Anthony (2004) researched the effectiveness of state growth management laws in controlling urban sprawl by examining the change in urban densities in 49 states over a 15-year period. He found that growth-managed states generally experienced a lesser density decline than states without growth management, but experienced a decline nonetheless. Regression analysis revealed that state growth management programs did not have a statistically significant effect in checking sprawl.

Carruthers (2002) examined the impact that alternative state planning frameworks have on five dimensions of urban development: density, the spatial extent of urbanized land area, property value, public expenditures on infrastructure, and population change. Outcome measures were modeled for a cross-section of 283 metropolitan counties. Findings suggest that state growth management programs with strong consistency requirements and enforcement mechanisms hold more promise for reducing urban sprawl.

EBN agree with GR that the most effective "cure” for sprawl may be simply "getting the prices right." Typically, local utilities such as water and wastewater are charged to users based on average system-wide costs (see Nelson, Nicholas and Juergensmeyer 2009). Thus, low-cost areas which tend to be higher density subsidize high-cost areas. The trouble is there are not many empirical studies associating differential utility pricing with urban form, probably because the vast majority of local governments do not price utilities based on geographic/location variation.

One city, Albuquerque, New Mexico, has done the next best thing; it varies impact fees by cost of providing new infrastructure based on location. The policy, implemented in 2004 (three years before the housing market crashed), resulted in the same new residential unit paying \$350 in the "fully served" parts of the city and more than $\$ 5,000$ in the partially served parts. In the two years before the policy was implemented, roughly 31 percent of all new residential permits were in the fully served areas. In the two years after implementation, roughly 52 percent of all residential permits were in the fully served areas. More dramatically: in the year before implementation only 26 percent of permitted units were in the fully served area but in the second year after full implementation the figure was 70 percent. Although an isolated instance and limited only to impact fees, it would appear that pricing public facilities properly can affect urban development patterns. ${ }^{5}$

\footnotetext{
${ }^{5}$ Analysis by Arthur C. Nelson using data provided by Susan Johnson of the City of Albuquerque, New Mexico.
} 


\section{Areas of Consensus}

There remain significant differences in opinions and judgments between ENB and GR on compactness vs. sprawl issues, but there are also many points of agreement, some with qualifications.

i. Both groups accept that society is permeated with both market failure and government failure. However, ENB believe that market failure is the more critical, while GR emphasize government failure.

ii. Government intervention is necessary However, there are two major differences. First, ENB promote a much more proactive role, whereas GR suggest more limited government. Second, ENB are comfortable with a regulatory approach; almost all GR's interventionist strategies rely on market incentives/disincentives.

iii. Both argue that residential preferences are a major determinant of future urban form and that housing choices are important. The only difference here is that ENB via Nelson's research have very strong predictions for 2025 leading to a major shift towards compact development, whereas GR (with a strong adherence to short-term analysis) are more open-minded about future trends. Nevertheless, if residential preferences change significantly, market supply will respond and the average density of new housing will increase.

iv. There is agreement that research has given priority to design and formulation and insufficient attention to implementation. For example, there have been relatively few ex-post evaluations of New Urbanist communities.

v. Both parties agree that some types of regulation, e.g, many zoning ordinances, interfere with the operation of land markets and flexibility in building types (both residential and commercial).

vi. There is agreement that self-selection is important especially with respect to transit ridership. However, as pointed out by ENB and supported by several research studies, after correcting for self-selection by including demographic and other socioeconomic control variables, there still remains a significant relationship between certain attributes of the built environment and some dimensions of travel behavior.

vii. Research into multidimensional measures of sprawl is both interesting and useful. However, GR are somewhat concerned about the proliferation of indices and lack of agreement on the definition of sprawl.

viii. Although ENB appear somewhat uncomfortable with the results, they accept that compact cities do not lead to shorter commuting times because of higher levels of congestion in central cities and the fact that longer suburban trip lengths are more than offset by faster trip speeds. GR's 1997 position still appears to hold.

\section{Conclusions}

ENB's component of this paper is proactive, with advocacy positions that lead naturally into an emphasis on planning interventions (although Bae is somewhat more centrist, she also leans towards the advocacy group). GR are more reactive, in line with their strong belief in market forces (but still in favor of policy interventions that rely much more on fees and price adjustments tan on command and control and/or regulations). Although parts of this paper attempt to reach some degree of consensus, it remains clear that the issues have not been resolved. On the contrary, the mound of 
new research since 1997 has added more complexity making resolution even more difficult.

How population change may affect the quality of life and economic well-being of Americans is controversial.. Another long-term projection of significant population growth is unlikely (unless we open up much more immigration) because so many countries (affected by fertility decline and the aging of population) are facing a future of population decline. ENB believe that the evidence is mounting that compact development may confer more benefits with fewer costs than urban sprawl; GR dissents unless the case for a major change in residential preferences is overpowering. Also, planning and policy mechanisms for achieving compact development remain elusive. 


\section{References}

Alberti, M. (1999). Urban Patterns and Environmental Performance: What Do We Know? Journal of Planning Education and Research, 19, 151-163.

American Planning Association, Classic Articles, accessed 3/31/06 www.planning.org/japa/libpart3.htm

Aytur, S. A., Rodruiqez, D. A., Evenson, K. R., Catellier, D. J. (2008). Urban containment policies and physical activity: A time-series analysis of metropolitan areas, 1990-2002. American Journal of Preventative Medicine, 34(4), 320-332.

Andrews, C.J. (2008). Greenhouse gas emissions along the rural-urban gradient. Journal of Environmental Planning and Management, 51(6), 847-870.

Anthony, J. (2004). Do state growth management regulations reduce sprawl? Urban Affairs Review, 39(3), 376-397.

Bae, C.-H. C. (2007), “Containing Sprawl,” 36-52, in G. J. Knaap, H.A. Huiccou, K. J. Clifton, and J.W. Frece, eds. Incentives, Regulations and Plans. Cheltenham, U.K.: Edward Elgar.

Bae, C.-H. C. (2004a), "Immigration and Densities: A Contribution to the Compact Cities and Sprawl Debate,” in C.-H. C. Bae and H.W. Richardson, eds. Urban Sprawl in Western Europe and the United States. Aldershot, UK: Ashgate.

Bae, C._H. C. (2004b), “Cross-Border Impacts of Growth Management Programs: Portland, Oregon, and Clark County, Washington,” pp. 95-111, in J. Grant, P. Marcotullio and A. Sorensen, eds. Towards Sustainable Cities: East Asian, North American and European Perspectives on Managing Urban Regions. Aldershot, UK: Ashgate.

Bae, C.-H. C. (2002), “Orenco Station, Portland, Oregon: A Successful Transit Oriented Development Experiment?” Transportation Quarterly, 56:3 (2002), 9-15.

Bauman, A. E., \& Bull, F. C. (2007). Environmental correlates of physical activity and walking in adults and children: A review of reviews. London, U.K.: National Institute of Health and Clinical Excellence.

Beito,D.T., P. Gordon and A. Tabarrok (2002), The Voluntary City. Ann Arbor: University of Michigan Press.

Bento, Antonio M., Maureen L. Cropper, Ahmed M. Mobarak, and Katja Vinha. 2003. The Impact of Urban Spatial Structure on Travel Demand in the United States. Washington, DC: World Bank.

Bertaud, A. and H.W. Richardson (2004), “Transit and Density: Atlanta, the United States and Western Europe,” in H. W. Richardson and C.H.-C.Bae, eds., Urban Sprawl in Western Europe and the United States. Aldershot: Ashgate.

Blakeley, E. and M.G. Snyder (1997), Fortress America: Gated Communities in the United States. Washington, DC: Brookings Institution Press.Burchell, Robert W., 
Naveed Shad, David Listokin, Hilary Phillips, Anthony Downs, Samuel Seskin, Judy S. Davis, Terry Moore, David Helton, and Michelle Gall. 1998. The Costs of Sprawl-Revisited. Washington, DC: Transportation Research Board.

Burchell, R.W., Lowenstein, G., Dolphin, W.R., Galley, C.C., Downs, A., Seskin, S., Still, K.G., \& Moore, T. (2002). Costs of Sprawl -- 2000. Transit Cooperative Research Program (TCRP) Report 74, published by Transportation Research Board, Washington, D.C.

Belden Russonello \& Stewart (2004). National Survey on Communities. Washington, D.C.: National Association of Realtors and Smart Growth America. www.brspoll.com/Reports/Smart\%20Growth.pdf.

Badoe, D.A. and Miller, E.J. (2000). Transportation-Land-Use Interaction: Empirical Findings in North America, and Their Implications for Modeling. Transportation Research Part D, 5: 235-263.

Bhat, C.R. \& Eluru, N. (2009). A Copula-based approach to accommodate residential self-selection effects in travel behavior modeling. Transportation Research Part B, 43(7), 749-765.

Burchfield, M., Overman, H.G., et al. (2005). Causes of Sprawl: A Portrait From Space. Quarterly Journal of Economics, 121(2): 587-633.

Can, A. 1990. The measurement of neighbourhood dynamics in urban house prices. Economic Geography 66: 254-272.

Can, A. 1992. Specification and estimation of hedonic housing price models. Regional Science and Urban Economics 22: 453-477.

Canadell, J.G , C. Le Quéré, M. Raupach et al. (2007). Contributions to Accelerating Atmospheric CO2 Growth from Economic Activity, Carbon Intensity, and Efficiency of Natural Sinks, Proceedings of the National Academies of Science, Early Edition. www.pnas.org/cgi/reprint/0702737104v1

Cao, X. (2010). Exploring causal effects of neighborhood type on walking behavior using stratification on the propensity score. Environment and Planning A, 42(2), 487504.

Cao, X., Mokhtarian, P.L., and Handy, S.L. (2009). Examining the Impacts of Residential Self-Selection on Travel Behaviour: A Focus on Empirical Findings.Transport Reviews, 29(3): 359-395.

Cao, X., Xu, Z., \& Fan, Y. (2009, January). Exploring the connections among residential location, self-selection, and driving behavior: A case study of Raleigh, NC. Paper presented at the 89th annual meeting of the Transportation Research Board.

Carruthers, J.I. (2002). The Impacts of State Growth Management Programmes: A Comparative Analysis. Urban Studies, 39(11), 1959-1982. 
Carruthers, J.I. \& Ulfarsson, G.F. (2003) Urban Sprawl and the Cost of Public Services. Environment and Planning B: Planning and Design, 30: 503-522.

Cho, S., Chen, Z., Yen, S.T., and Eastwood, D.B. (2006) The Effects of Urban Sprawl on Body Mass Index: Where People Live Does Matter, The 52nd Annual ACCI Conference, Baltimore, Maryland, March 15-18.

Committee on Physical Activity, Health, Transportation, and Land Use (2005). Does the Built Environment Influence Physical Activity? Examining the Evidence-Special Report 282, National Academies of Science, Washington, D.C.

Cooper, J., Ryley, T., \& Smyth, A. (2001). Energy Trade-offs and Market Responses in Transport and Residential Land-use Patterns: Promoting Sustainable Development Policy. Urban Studies, 38(9), 1573-1588.

Cortright, J. (2008). Driven to the Brink. How the Gas Price Spike Popped the Housing Bubble and Devalued the Suburbs. CEOs for Cities, Portland, OR. http://www.ceosforcities.org/newsroom/pr/files/Driven\%20to\%20the\%20Brink\%20FI NAL.pdf

Crane, R. (2000). The Influence of Urban Form on Travel: An Interpretive Review. Journal of Planning Literature, 15(1), 3-23.

Cutsinger, J., Galster, G., Wolman, H., Hanson, R., and Towns, D. (2005). Verifying the Multi-Dimensional Nature of Metropolitan Land Use: Advancing the Understanding and Measurement of Sprawl. Journal of Urban Affairs, 27(3): 235259.

Dawkins, C. J. and A. C. Nelson (2003) "Statewide Growth Management Policy and Central City Revitalization.” Journal of the American Planning Association. 69(4): 381-396.

Delucchi, M. (1998) The Annualized Social Cost of Motor-Vehicle Use in the United States, Based on 1990-1991 Data: Summary of Theory, Methods, Data, and Results, Institute of Transportation Studies, University of California, Davis.

Doyle, S., Kelly-Schwartz, A., Schlossberg, M., and Stockard, J. (2006). Active Community Environments and Health: The Relationship of Walkable and Safe Communities to Individual Health. Journal of the American Planning Association, 72(1), $19-31$.

Dubin, R. A. 1998. Predicting house prices using multiple listings data. Journal of Real Estate Finance and Economics, 17, 35-60.

Duncan, M. 2011. The impact of transit-oriented development on housing prices in San Diego, CA. Urban Studies, 48(1), 101-126.

Eid, J., Overman, H.G., Puga, D., \& Turner, M.A. (2008). Fat City: Questioning the Relationship Between Urban Sprawl and Obesity. Journal of Urban Economics, 63, 385-404. 
Energy Information Agency. (2008). World Liquids Consumption by Region, Reference Case, 1990-2030. Washington, DC: U.S. Department of Energy.

Energy Information Agency. (2010). International energy outlook 2010. Washington, DC: U.S. Department of Energy.

Emanuel, K. (2005). Increasing Destructiveness of Tropical Cyclones over the Past 30 Years. Nature, 436: 686-688.

Echenique, M., A.J. Hargreaves and G. Mitchell (2012), “Growing Cities Sustainingly: Does Urban Form Really Matter?” Journal of the American Planning Association, 78(2), 121-137.

Ewing, R. (1997). Is Los Angeles-Style Sprawl Desirable? Journal of the American Planning Association, 63: 107-126.

Ewing, R. (2006). Does Growth Management Work? How Do You Decide?” Planning, November, 57.

Ewing, R. (2007) Finding Happiness in Public-Private Partnerships. The Case for Case Studies,” Planning, January, 53

Ewing, R., Bartholomew K., Winkelman, S., Walters, J., and Chen, D. (2008). Growing Cooler: The Evidence on Urban Development and Climate Change, Washington, DC: Urban Land Institute.

Ewing, R., Brownson, R. C., and Berrigan, D. (2006). Relationship between urban sprawl and weight of United States youth. American Journal of Preventive Medicine, 31(6), 464-474.

Ewing, R. and Cervero, R. (2001). Travel and the Built Environment. Transportation Research Record, 1780: 87-114.

Ewing, R., Pendall, R., and Chen, D. (2002). Measuring Sprawl and Its Impact. Washington D.C: Smart Growth America.

Ewing, R. and Rong, F. (2008). The Impact of Urban Form on U.S. Residential Energy Use. Housing Policy Debate, 19(1): 1-30.

Ewing, R., Schmid, T., Killingsworth, R., Zlot, A., and Raubenbush, S. (2003). Relationship Between Urban Sprawl and Physical Activity, Obesity, and Morbidity. American Journal of Health Promotion, 18(1), 47-57.

Ewing, R., Schieber, R., and Zegeer, C. (2003). Urban Sprawl as a Risk Factor in Motor Vehicle Occupant and Pedestrian Fatalities, American Journal of Public Health 93: 1541-1545. 
Frank, L. D., Andersen, M. A., \& Schmid, T. L. (2004). Obesity Relationships with Community Design, Physical Activity and Time Spent in Cars. American Journal of Preventive Medicine, 27(2), 87-96.

Fulton, W., Pendall, R. et al. (2001). Who Sprawls Most? How Growth Patterns Differ across the U.S. Washington, DC, Brookings Institution.

Galster, G., Hanson, R., Ratcliffe, M., Wolman, H., Coleman, S., and Freihage, J. (2001). Wrestling Sprawl to the Ground: Defining and Measuring an Elusive Concept. Housing Policy Debate, 12(4): 681-717.

Gebel, K., Bauman, A.E., \& Petticrew, M. (2007). The physical environment and physical activity: A critical appraisal of review articles. American Journal of Preventive Medicine, 32(5), 361-369.

Glaeser, E., Kahn, M., and Chu, C. (2001). Job Sprawl: Employment Location in U.S. Metropolitan Areas, Washington, DC: Brookings Institution.

Gordon, P and H.W. Richardson (2007), "The Debate on Sprawl and Compact Cities: Thoughts Based on the Congress of New Urbanism Charter," (with P. Gordon) in H.S. Geyer, ed., International Handbook of Urban Policy,Vol. 1. Cheltenham: Edward Elgar.

Gordon, P. and H. W. Richardson (2004), "U.S. Population and Employment Trends and Sprawl Issues," 217-235, in H. W. Richardson and C.-H. C. Bae, eds., Urban Sprawl in Western Europe and the United States. Aldershot: Ashgate.

Gordon, P. and H.W. Richardson (2001), "The Sprawl Debate: Let Markets do the Planning” Publius, 31:2.

Gordon, P. and H.W. Richardson (2000), Critiquing Sprawl's Critics . Washington DC: Cato Institute Policy Analysis No. 365.

Gordon, P. and H.W. Richardson (2001), "Transportation and Land Use," in R. Holcombe and S. Staley (eds.) Smarter Growth: Market-Based Strategies for Land Use Planning in the $21^{\text {st }}$ Century. Westport, Conn: Greenwood Press.

Gordon, P. and H.W. Richardson (1993), "Market Planning: Oxymoron or Commonsense," Journal of the American Planning Association, 59(3).

Gordon, P. and Richardson, H. (1997). Are Compact Cities a Desirable Planning Goal? Journal of the American Planning Association, 63: 95-106.

Gordon, T.M. (2004), Planned Developments in California: Private Communities and Public Life. San Francisco, CA: Public Policy Institute of California.

Greene, D. L., Kahn, J. R., and Gibson, R. C. 1999. Fuel economy rebound effect for U.S. household vehicles. Energy Journal, 20(3), 1-31 
Handy, S.L. (1996). Understanding the Link between Urban Form and Nonwork Travel Behavior. Journal of Planning Education and Research, 15(3): 183-198.

Handy, S., Sallis, J.F., Weber, D., Maibach, E. and Hollander, M. (2008) Is Support for Traditionally Designed Communities Growing? Evidence From Two National Surveys, Journal of the American Planning Association, 74(2): 209-221.

Handy, S., J. Sallis, D. Weber, E. Maibach, and M. Hollander. 2008. Is Support for Traditionally Designed Communities Growing? Evidence from Two National Surveys. Journal of the American Planning Association 74 (2): 209-221.

Haubrich, J. G., \& Meyer, B. (2007). Peak oil. Cleveland, OH: Federal Reserve Bank of Cleveland.

Heath, G.W., Brownson, R.C., Kruger, J., Miles, R., Powell, K.E., Ramsey, L.T., \& the Task Force on Community Preventive Services. (2006). The Effectiveness of Urban Design and Land Use and Transport Policies and Practices to Increase Physical Activity: A Systematic Review. Journal of Physical Activity and Health, 3: 55-76.

Hortas-Rico, M. and A. Sole-Oile (2010), "Does Urban Sprawl Increase the Costs of Providing Public Services? Evidence from Spanish Municipalities," Urban Studies, 47(7): 1513-1540.

Intergovernmental Panel on Climate Change (IPCC). (2007). Climate Change 2007: The Physical Science Basis, Summary for Policymakers. Working Group I contribution of the Intergovernmental Panel on Climate Change: Fourth Assessment Report. www.ipcc.ch/.

Joshu, C.E, Boehmer, T.K., Ewing, R., \& Brownson, R.C. (2008). An Examination of Personal, Neighborhood and Urbanization Correlates of Obesity in the United States," Journal of Epidemiology and Community Health, 62: 202-208.

Jun, M.-J. (2008), “Are Portland's Smart Growth Policies Related to Reduced Automobile Dependence?” Journal of Planning Education and Research, 28(1), 100 107.

Jun, M.J. (2004), “The Effect of Portland's Urban Growth Boundary on Urban Development Patterns and Commuting,” Urban Studies, 41(7), 1333-1348.

Kahn, M.E. (2007). The Quality of Life in Sprawled versus Compact Cities. In Transport, Urban Form and Economic Growth, OECD Publishing.

Kelly-Schwartz, A. C., Stockard, J., Doyle, S., \& Schlossberg, M. (2004). Is Sprawl Unhealthy?: A Multilevel Analysis of the Relationship of Metropolitan Sprawl to the Health of Individuals. Journal of Planning Education and Research, 24, 184-196.

Kenworthy, J., Laube, F. (1999). A global review of energy use in urban transport systems and its implications for urban transport and land-use policy. Transportation Quarterly, 53(4), 23-48. 
Ladd, H. (1992), "Population Growth, Density and the Costs of Providing Public Services,” Urban Studies, 29(2), 273-295.

Leinberger, C.B. (2008). The Option of Urbanism: Investing in a New American Dream, Washington, D.C.: Island Press.

Levine, J. (2006). Zoned Out: Regulation, Markets, and Choices in Transportation and Metropolitan Land Use, Resources for the Future, Washington, D.C.

Litman, T. (2009). Transportation Cost and Benefit Analysis II - Literature Review, Victoria Transport Policy Institute, Victoria, British Columbia.

http://www.vtpi.org/tca/tca02.pdf

Lopez, R. (2004). Urban Sprawl and Risk for Being Overweight or Obese. American Journal of Public Health, 94(9), 1574-1579.

Lopez, R. and Hynes, H.P. (2003). Sprawl in The 1990s: Measurement, Distribution, and Trends. Urban Affairs Review, 38(3): 325-355.

Madsen, T. and Figdor, E. (2007). When It Rains, It Pours: Global Warming and the Rising Frequency of Extreme Precipitation in the United States. Boston: Environment America Research \& Policy Center.

http://www.environmentamerica.org/uploads/oy/ws/oywshWAwZyEXPsabQKd4A/When-It-Rains-It-Pours----US---WEB.pdf.

Malpezzi, S. and Guo, W. (2001). Measuring "Sprawl": Alternative Measures of Urban Form in U.S. Metropolitan Areas, Madison: Center for Urban Land Economics Research, University of Wisconsin.

McMillan T.E. (2005). Urban Form and a Child's Trip to School: The Current Literature and a Framework for Future Research. Journal of Planning Literature 19(4): 440-456.

McMillan T. E. (2007). The relative influence of urban form on a child's travel mode to school. Transportation Research A, 41(1), 69-79.

Nasser, H.E. and Overberg, P. (2001) What You Don’t Know about Sprawl: Controlling Development a Big Concern, but Analysis Has Unexpected Findings, USA Today, February 22, 2001.

National Academy of Sciences. (2009). Driving and the Built Environment: The Effects of Compact Development on Motorized Travel, Energy Use, and CO2 Emissions, published by the Transportation Research Board, Washington, D.C.

Nelson, A.C. (2006). Leadership in a New Era, Journal of the American Planning Association, 72(4): 393-407.

Nelson, A.C., C. J. Dawkins and T. W. Sanchez (2007) Urban Containment and Society. Hampshire, UK: Ashgate. 
Nelson, A. C., J. C. Nicholas and J. C. Juergensmeyer (2009). Impact Fees: Principles and Practice of Proportionate-Share Development Fees. Chicago, IL: American Planning Association.

Nelson, A. C. and T.W. Sanchez (2005). The Effectiveness of Urban Containment Regimes in Reducing Exurban Sprawl. DISP 160: 42-47.

Nelson, A. C., T. W. Sanchez and C. J. Dawkins (2004). Urban Containment and Residential Segregation: A Preliminary Investigation. Urban Studies. 41(2): 423-440.

Nelson, A. C., et al. (2004). Urban Containment and Central City Revitalization. Journal of the American Planning Association 70(4): 411-425.

Nelson, A. C. and J. B. Duncan (1995). Principles and Practice of Growth Management. Chicago, IL: American Planning Association.

Nelson, A. C., C. J. Dawkins and T. W. Sanchez (2005). The Effect of Urban Containment and Mandatory Housing Elements on Racial Segregation in US Metropolitan Areas. Journal of Urban Affairs 26(3): 339-350.

Nelson, A. C., K. Foster (1999). "Metropolitan Governance Structure and Economic Performance." Journal of Urban Affairs, 21(3): 309-324.

Nelson, A. C. and D. R. Peterman (2000). "Does Growth Management Matter?" Journal of Planning Education and Research. 19(3): 277-286.

Office of Technology Assessment (1995) The Technological Reshaping of Metropolitan America. Washington, D.C.: Congress of the United States, 193-218.

Papas, M.A., Alberg, A.J., Ewing, R., Helzlsouer, K.J., Gary, T.L. and Klassen, A.C. (2007). The Built Environment and Obesity: A Review of the Evidence.

Epidemiologic Reviews, 29(1): 129-143

Peiser, Richard B. (1989). Density and Urban Sprawl, Land Economics, 65(3): 194204.

Pendall, R. (1999). Do land-use controls cause sprawl? Environment and Planning B: Planning and Design, 26 (4) 555 - 571

Plantinga, A. J., \& Bernell, S. (2007). The association between urban sprawl and obesity: Is it a two-way street? Journal of Regional Science, 45(3), 473-492.

Pont, K., Ziviani, J., Wadley, D., Bennett, S., \& Abbott, R. (2009). Environmental correlates of children's active transportation: A systematic literature review. Health \& Place, 15(3), 827-840.

Richardson, H.W. and P. Gordon (2009), "The Implications of the Breaking the Logjam Project for Smart Growth and Urban Land Use,” New York University Environmental Law Journal 17(1), 529-558, 2009. 
Richardson, H.W. and P. Gordon (2000), "Compactness vs. Sprawl: America's Future," in M. Echenique and A. Saint (eds.) Cities for the New Millenium. London: SPON.

Richardson, H.W. and C.H. C. Bae, eds. (2004), Urban Sprawl in Western Europe and the United State. Aldershot, UK: Ashgate.

Richardson, H.W. and P. Gordon (2004), "Sustainable Portland? A Critique, and the Los Angeles Counterpoint,” 132-46, in A. Sorensen, P.J. Marcotullio and J. Grant, eds. Towards Sustainable Cities: East Asian, North American and European Perspectives on Managing Urban Regions. Aldershot: Ashgate

Richardson, H.W. and C.-H. C. Bae (2005), "Transportation and Urban Compactness," in K.J. Button and D. Hensher, eds., Handbook of Transport Geography and Spatial Systems. Amsterdam: Elsevier.

Rodriguez, D.A., Targa, F., \& Aytur, S.A. (2006). Transport Implications of Urban Containment Policies: A Study of the Largest Twenty-five US Metropolitan Areas. Urban Studies, 43(10), 1879-1897.

Rundle, A., Roux, A. V. D., Freeman, L. M., Miller, D., Neckerman, K. M., \& Weiss, C. C. (2007). The urban built environment and obesity in New York City: A multilevel analysis. American Journal of Health Promotion, 21(4): 326-334.

Saelens, B.E. and Handy, S. (2008). Built environment correlates of walking: A review. Medicine \& Science in Sports \& Exercise, 40(S), S550-S567.

Saelens, B.E., Sallis, J.F., and Frank, L.D. (2003). Environmental Correlates of Walking and Cycling: Findings from the Transportation, Urban Design, and Planning Literatures. Annals of Behavioral Medicine, 25(2): 80-91.

Salon, D. (2006). Cars and the city: An investigation of transportation and residential location choices in New York City. Davis, CA: Agricultural and Resource Economics, University of California, Davis.

Sartori, J., Moore, T., and Knaap, G. (2011). Indicators of Smart Growth in Maryland. National Center for Smart Growth Research and Education, University of Maryland.

Saunders, M.J., Kuhnimhof, T, Chlond, B., da Silva, A.N. (2008). Incorporating transport energy into urban planning. Transportation Research Part A, 42(6), 874882.

Small, K. A. and Van Dender, K. 2007. Fuel efficiency and motor vehicle travel: The declining rebound effect. Energy Journal, 28(1), 25-51. 
Stead, D. and Marshall, S. (2001). The Relationships between Urban Form and Travel Patterns. An International Review and Evaluation. European Journal of Transport andInfrastructure Research. 1(2): 113-141.

Stern, N. (2007). The Economics of Climate Change: The Stern Review. Cambridge, United Kingdom: Cambridge University Press. www.hmtreasury.gov.uk/independent_reviews/stern_review_economics_climate_change/stern review_report.cfm.

Stone, B. (2008). Urban Sprawl and Air Quality in Large U.S. Cities. Journal of Environmental Management, 86:688-698.

Schweitzer, L and Zhou, J. (2010). Neighborhood Air Quality Outcomes in Compact and Sprawled Regions, Journal of the American Planning Association, 76(3): 363-371

Sturm, R. and Cohen, D. (2004). Suburban Sprawl and Physical and Mental Health. Public Health, 118(7): 488-496.

Trowbridge, M.J., Gurka, M.J., O’Connor, R. (2009). Urban Sprawl and Delayed Ambulance Arrival in the United States. American Journal of Preventive Medicine. 37(5), 428-432. .

ULI-the Urban Land Institute and PricewaterhouseCoopers LLP (2005). Emerging Trends in Real Estate 2005. Washington, D.C.

ULI-the Urban Land Institute and PricewaterhouseCoopers LLP (2006). Emerging Trends in Real Estate 2006. Washington, D.C.

ULI-the Urban Land Institute and PricewaterhouseCoopers LLP (2007). Emerging Trends in Real Estate 2007. Washington, D.C.

U.S. Environmental Protection Agency. (2003). Characteristics and Performance of Regional Transportation Systems. Washington, DC.

U.S. Environmental Protection Agency. (2000). Emission facts: Average annual emissions and fuel consumption for passenger cars and light trucks, published by the Office of Transportation and Air Quality, Washington, D.C.

U.S. Environmental Protection Agency. 2010. Our nation's air: Status and trends through 2008. Washington, DC.

U.S. Government Accountability Office (GAO). (2007). Crude oil: Uncertainty about future oil supply makes it important to develop a strategy for addressing a peak and decline in oil production. Washington, DC: Author. Retrieved March 21, 2008, from http://frwebgate.access.gpo.gov/cgi-bin/getdoc.cgi?dbname=gao\&docid=f:d07283.pdf

Waldheim, C. (2006), The Landscape Urbanism Reader. Princeton Architectural Press. 
Westerling, A.L., Hidalgo, H.G., Cayan, D.R., and Swetnam, T.W. (2006). Warming and Earlier Spring Increase Western U.S. Forest Wildfire Activity. Science, 313: 940943

http://www.sciencemag.org/cgi/rapidpdf/1128834.pdf.

Zhou, B., \& Kockelman, K. (2008). Self-selection in home choice: Use of treatment effects in evaluating relationship between built environment and travel behavior.

Transportation Research Record, 2077, 54-61.

Zhu, P. (2013), “Telecommuting, Household Commute and Location Choice,” Urban Studies, 50(12), 2441-2459.

Zhu, P. (2012), “Are Telecommuting and Personal Travel Complements or Substitutes?” Annals of Regional Science, 48(2), 619-639.

Zittel, W., \& Schindler, J. (2007). Crude oil: The supply outlook. Ottobrunn, Germany: Energy Watch Group. Retrieved June 30, 2008, from http://www.energywatchgroup.org/fileadmin/global/pdf/EWG_Oilreport_102007.pdf. 